\title{
FOREWORD: SOME THOUGHTS ON SAN FRANCISCO BAY AND ITS WETLANDS
}

Wetlands occur where land meets water. Wetlands, therefore, are not evenly spread over the surface of the Earth. Some areas, such as the Amazon and Siberia, have enormous wetlands, each of these being more than one million square kilometers. Most wetlands along the ocean coasts are much smaller, being limited on one side by uplands and on the other by ocean water that is too deep for rooted plants. The water levels in wetlands along coasts are influenced by tides, hence the general name tidal marsh. Tidal marshes can be further divided into two types, the narrow fringing marshes along steeper shorelines, and the somewhat larger areas of wetlands associated with estuaries and deltas. This book is about the latter type, wetlands in a large estuary, San Francisco Bay.

The steep and rocky shorelines of California offer few estuaries and deltas. San Francisco Bay is therefore an ecologically important exception. Indeed, it is the biggest estuary on the west coast of the New World (Nawi and Brandt 2008). Here, two rivers that collectively drain nearly $40 \%$ of California meet and empty into the Pacific Ocean. These rivers deposit silt, and they dilute ocean salinity. Depending upon how you do the calculations, these rivers have created from one to four thousand square kilometers of estuary and tidal marsh.

The rarity of such large wetlands on the West Coast magnifies their importance to wildlife. Millions of waterfowl using the Pacific flyway visit the wetlands and mudflats. The Dungeness crab, California halibut, and Pacific salmon all rely on the Bay as a nursery. Some 750 wildlife species, along with 120 species of fish, use the estuary (Nawi and Brandt 2008).

San Francisco Bay may be exceptional on the West Coast, but it should not be treated as an exception. This bay exemplifies all the general principles that drive the formation of estuaries around the world. In all such tidal wetlands, a physical template controls the kinds of wetlands that arise and the particular plant and animal species that live in the wetlands. In general, the physical template is created by the flood regime, the nutrients, and natural agents of disturbance such as fire and grazing (Keddy 2010). In estuaries, salinity is also an important factor. In San Francisco Bay, this template is created and controlled by tides near the coast but also by inputs of freshwater and sediment from the rivers, the Sacramento and San Joaquin. Together, such rivers carry freshwater into the Bay at an average rate of about 24 million acre-feet per year $(900$ $\left.\mathrm{m}^{3} / \mathrm{s}\right)$. The key ecological factors in the Bay are therefore (1) the area of silt and shoreline upon which wetland plants can potentially grow and (2) the salinity gradient, which ranges from fresh to saline. If you know how much of the Bay area is wet and how much wetland arises under each salinity regime, you can predict, rather well, the kinds of plants and animals that will occupy the Bay.

The salinity gradient, of course, varies. Pulses of freshwater from the rivers will reduce salin- 
ity, while periods of drought will lead to higher salinity. The range of variation and the extremes may be more important than the mean conditions. The idea that extreme conditions rather than mean conditions drive ecosystems has been around for a long time, but because extremes are often more difficult to observe and measure, we tend to overlook them. Tidal wetlands are a class of ecosystems where extremes must be considered.

San Francisco Bay was formed over a long series of geological events, the most recent being the general rise in sea levels at the end of the ice age some twenty thousand years ago. During each ice age, sea levels fall as water is stored in vast continental glaciers. At the end of each ice age, the water from melting glaciers steadily raises sea levels. During the maximum of the last ice age, sea levels were about $100 \mathrm{~m}$ lower, and one large river drained through a canyon that is now called Golden Gate, into the Pacific Ocean. That would have been a sight to see. The current bay, then, the one with which we are familiar, is a flooded river valley. Prior ice ages led to similar alterations in ecological conditions. This book sensibly includes a chapter on these events.

Here is another general principle that the Bay illustrates: global temperature and sea level are closely linked. Coastal wetlands are at great risk from changes in sea level, and whether you live in California, Louisiana, China, or Bangladesh, rising sea level from global warming is going to become an issue of overriding importance. Of course, at one time tidal marshes would move inland with rising sea levels, but now many are backed up against cities, and both the wetlands and the cities are in the path of tides and stormdriven surges. Chapter 6 by Tom Parker and coworkers has more to say explicitly about climate change, but if you pay attention, you will see that this theme emerges throughout the book. California, and Louisiana, could therefore lead the world in taking steps to control climate change. Or not.

Speaking of human impacts, the first human visitors to San Francisco Bay were generally agreed to be Asians who had walked across the Bering Strait during the last ice age. Some of their migrations may also have been along the coast, since ocean currents naturally carry objects from north to south and since many of the tribal cultures included the use of boats. We can say with some confidence that the first human visitors likely saw the Bay around 10,000 years ago, when sea levels were still somewhat lower. The first recorded visits by Europeans were by Spanish seafarers in the late $1700 \mathrm{~s}$. At this time the Bay had some $2,200 \mathrm{~km}^{2}$ of wetlands. Now, after several centuries of human development, that figure has fallen to only $125 \mathrm{~km}^{2}$-a $95 \%$ rate of loss of original wetland area (U.S. Geological Survey 2003) (Map 1).

The direct loss of wetlands over the last two centuries has been obvious. Large areas of wetland were filled with debris for development or cut off from the estuary by dikes to allow for agriculture. These direct impacts are fairly easy to map. Other factors, however, may be equally significant but less obvious. One of the greatest historical impacts of humans was hydraulic mining in the watershed in the 1860s. The debris was carried downstream, where it eventually filled in the eastern ends of the Bay. This not only changed the biology of the estuary but continues to this day to contribute to the expense of dredging, a significant federal subsidy to the shipping industry courtesy of the U.S. Army Corps of Engineers. Another significant impact was due to changes in the rivers themselves. Wetlands depend upon particular rhythms of high and low water levels, and every species, from fish to wading birds, times its life cycle to these highs and lows. Dams upstream disrupt the timing and duration of floods, thereby decreasing the area of wetlands and disrupting these cycles. Other effects from upstream disturbances such as deforestation and agriculture may be spread out more widely, but since the runoff eventually enters the rivers and concentrates in the Bay, these diffuse effects may be amplified in the Delta. The effects of changes in water quality, particularly with regard to nutrient levels, and toxic chemicals may therefore appear most severely in deltaic areas. Therefore, attempts to wisely manage the Bay may start with the most obvious local actions-infilling and diking-but eventually require that we consider human activities in the watershed as a whole. This requires us to expand our thinking-from considering first the remaining areas of wetlands themselves, through to thinking about the entire watershed that feeds water to these wetlandsthat is, the entire Central Valley of California.

The biological significance of the Bay is something I touched on above-think clouds of birds 
and schools of fish-and many of the later chapters in this book expand on this theme. We will let the authors speak for themselves, although this may be a good place to mention a recent book, San Francisco Bay: Portrait of an Estuary (words by John Hart and photographs by David Sanger), for a nontechnical treatment of these topics. And for a regional context to the Bay, two government scientists, Stephen Veirs and Paul Opler (1998), have written a succinct and nicely illustrated introduction to California, including both the original distribution of ecosystems and the many impacts of humans upon them.

Apart from its biological significance, the Bay also has considerable cultural significance. The book says less about this, so let me give four examples. The writer Samuel Clemens, better known as Mark Twain, moved to San Francisco in 1864, where he began his career. The Golden Gate Bridge is a national engineering icon and forms a part of the human cultural landscapefamiliar to people who have never seen the city except in films. San Francisco frequently appears in popular music - the 1967 hit "San Francisco (Be Sure to Wear Flowers in Your Hair)" became an iconic sound track to the cultural turmoil of the 1960s and to the war in Vietnam. The Bay also is an important location in films and television shows. For example, it is the site where a Klingon Bird of Prey crashes (in the future, when humans must return to the past to capture and release whales to repopulate Earth's oceans). This episode of Star Trek IV manages to capture both the 1986 and the future San Francisco, with a riveting scene of an alien spaceship flying under the Golden Gate Bridge. And, on the topic of popular entertainment, if you want a view of San Francisco in the time of Mark Twain, there is a pair of episodes of Star Trek: The Next Generation, called "Time's Arrow," where some of the crew return to San Francisco and even meet Samuel Clemens (and a young Jack London too). Of course there are many more cultural examples that could be mentioned, but the point to emphasize is that the fate of the Bay is not just an issue of interest to the local humans. The Bay is part of our human heritage and has significance far beyond the seven million or so people who actually live in the immediate area.

Returning to tidal wetlands, scientists have spent some decades trying to decide how to protect the existing wetlands and how to restore areas that have been degraded. There are many complicated technical issues that have to be considered, enough to keep some generations of biologists gainfully employed. At the same time, the issues are relatively simple. For those who live in the Bay Area, and those who watch from a distance, there are a few simple indicators we should be watching carefully. These are (1) the area of wetland, (2) the salinity levels in the Bay, (3) the amplitude and natural rhythm of high and low water levels as they change seasonally, and (4) the quality of the water in the rivers feeding the Bay. The good news is that if we get the water right, a lot of the other issues will fall into place naturally. That is where the topic of marsh restoration arises: the more we can restore the quantity and quality of water to natural conditions, the more we can protect the wetlands that still survive and, equally, restore the wetlands that have been degraded or lost. The last two chapters in this book tell us about recent progress in restoration. Here is where you will also have to master a new vocabulary-not the names of plants and animals, but the names of government agencies, research teams, and working groups. Most important among these is CALFED (California Bay-Delta Program and its successor, California Bay-Delta Authority), a joint federal-state agency that may, or may not, achieve the goal of sensibly managing the area. While "CALFED can provide a model for a functioning, collaborative ecosystem restoration program, it also demonstrates the difficulty of any effort to achieve success in resolving long-standing conflicts that involve both the protection and the utilization of a scarce and unique natural resource" (Nawi and Brandt 2008, 113). Of course, if CALFED does not survive, something will have to replace it, and the same problems will have to be solved: too many people vying for scarce resources, principally freshwater and food.

This conveniently brings us back to general lessons that extend well beyond the Bay. We have already noted some general scientific principles: how the Bay illustrates the distribution of tidal wetlands around the world, how a few key environmental filters control tidal wetlands, how pulses of freshwater and periods of drought create natural extremes, how wetlands provide valuable ecological services, and how we can restore ecosystems by restoring the natural filters, including their normal patterns of variation.

There is one more general principle that this 
book illustrates. We can view an area like San Francisco Bay as a test of our humanity. By humanity I mean a range of mental traits including compassion and rational behavior. Will we, like the shortsighted citizens of Easter Island, destroy ourselves by destroying our natural environment? Are greed, selfishness, and ignorance really so deeply rooted in our psyche that we cannot coexist with the other species with whom we share the Earth? That is the question. It is time to decide. Thus, somewhere on the shelf that holds this book, you may wish to also add Ronald Wright's concise book, A Short History of Progress. How will we judge our progress? Although this book is about science conducted by humans, those in the jury are mostly not human. Ultimately the wetlands exist because of, and are used by, nonhumans, from the marsh grasses to the wading birds. If we do our part-by getting the water right-these other species will continue using the Bay. Scientists can study the history of the Bay, document the lives of the species that live there, and designate the ecological indicators for measuring progress in restoration. But in the end, the other species in the Bay will be the judge of whether we have done our jobs properly as scientists and citizens.

PAUL KED DY

\section{LITERATURE CITED}

Hart, J., and D. Sanger. 2003. San Francisco Bay: Portrait of an estuary. University of California Press, CA. www.sanfranciscobaybook.com.

Keddy, P. A. 2010. Wetland ecology: Principles and conservation. 2nd ed. Cambridge University Press, Cambridge, UK.

Nawi, D., and A.W. Brandt. 2008. The California BayDelta: The challenge of collaboration. In Largescale ecosystem restoration: Five case studies from the United States, edited by M. Doyle and C. A. Drew, 112-146. Island Press, Washington, DC.

U.S. Geological Survey. 2003. Coastal wetlands and sediments of the San Francisco Bay system. USGS Fact Sheet. http://pubs.usgs.gov/fs/coastal-wet lands/index.html.

Veirs, S. D., and P. A. Opler. 1998. California. In Status and trends of the nation's biological resources, edited by M. J. Mac, P.A. Opler, C. E. Puckett Haecker, and P. D. Doran, 593-644. 2 vols. U.S. Department of the Interior, U.S. Geological Survey, Reston, VA.

Wright, R. A. 2004. A short history of progress. Anansi Press, Toronto, ON. 